\title{
Culture and its influence on an increase of cervical cancer cases in Angola
}

\author{
Cultura e a sua influência no aumento dos casos de câncer cervical em Angola \\ João Wilson da Rocha1,20
}

\begin{abstract}
Cervical cancer is the second most common cancer among women worldwide and also in Angola. Its highest incidence occurs in women between 45 and 55 years of age; the main etymological factor is the infection with human papilloma virus (HPV), whose DNA is detectable in more than $99 \%$ of cases. This article review demonstrates some sociocultural, socio-economic, ethnic, and linguistic factors as influencing the increase of cervical cancer cases in Angola.
\end{abstract}

Keywords: Uterine neoplasms; Culture; Angola.

\begin{abstract}
RESUMO
O câncer cervical é o segundo tipo de câncer mais comum entre as mulheres em todo o mundo e também em Angola. Sua incidência maior ocorre em mulheres entre 45 e 55 anos de idade; o principal fator etimológico é a infecção pelo papiloma vírus humano (HPV), cujo DNA é detectável em mais de $99 \%$ dos casos. A revisão deste artigo demonstra alguns fatores socioculturais, socioeconômicos, étnicos e linguísticos que influenciam o aumento dos casos de câncer cervical na Angola.

Descritores: Neoplasias uterinas; Cultura; Angola.
\end{abstract}

1. Clinica Girassol, Oncology - Luanda - Angola - Angola.

2. Instituto Angolano do Controle do Câncer (IACC), Luanda - Angola.

Financial support: none to declare.

Conflicts of interest: The authors declare no conflict of interest relevant to this manuscript.

Correspondence author: João Wilson da Rocha.

E-mail: jwpr10@gmail.com / jwpr@sapo.ao 


\section{DEAR EDITOR,}

The word 'cancer' has a Greek origin. The surface of a solid tumor, with its vascularization in various directions, suggests a multi-legged crab. Cancer comprisesasignificant group of diseasescharacterized by unregulated cell growth. In cancer, the cells divide and grow wildly, forming 'malignant tumors'.

Cervical cancer is the third most common type of cancer among women worldwide, with approximately $80 \%$ of cases occurring in developing countries. The highest incidence rates of this neoplasm are observed in South America, Africa, and South Asia.

It is estimated that more than 266,000 women die each year from cervical cancer, and $87 \%$ of these deaths occur in less developed regions around the world, notably in the WHO African Region. If nothing is done, the death toll will reach 416,000 by 2035 . In Sub-Saharan Africa, 34.8 new cases of cervical cancer are diagnosed annually by 100,000 women, and 22.5 out of 100,000 women die from this disease.

The intraepithelial neoplasia (CIN), adenocarcinoma, and squamous (or squamous cell) carcinoma of the cervix share many risk factors. These include early onset of sex life, multiple sexual partners, promiscuity, history of sexually transmitted disease (such as Chlamydia trachomatis and herpes simplex virus), multiparity, immunosuppression, low socioeconomic status, prolonged oral contraceptive use, and previous history of dysplasia, and scaly areas of the vulva or vagina. In the case of squamous cell carcinoma, smoking is also a risk factor.

The main etiological factor of cervical cancer is HPV infection, whose DNA is detected in over $99 \%$ of cases. These viruses are transmitted primarily through sexual contact and approximately $20 \%$ of the sexually active population is infected. HPV is responsible for over $99.7 \%$ of cervical cancers, about $90 \%$ of the anal canal, $70 \%$ of vulva and vagina, $70 \%$ oropharynx, and $60 \%$ penis.

The HPV infection is widespread in the population. More than $50 \%$ of women with active sex lives acquire the virus at some point in their lives. Infection is a necessary but not sufficient condition for the development of the disease. When the infection becomes persistent, the time between initial infection and the development of invasive dysplasia/cancer is approximately 15 years, although faster courses have been described.

From infection to the development of invasive cancer, four stages are described:

1. Infection of the transformation zone metaplastic epithelium by oncogenic virus strain;

2. Persistence of infection;

3. Progression of a clone of infected epithelial cells to a precancerous lesion (dysplasia and intraepithelial neoplasia);

4. Development of carcinoma with invasion of the epithelium basement membrane.

According to data from the Global Cancer Observatory (2018), ${ }^{[\mathrm{x}]}$ there was an increase in cases in Angola, in 2018.

Factors that influence increasing rates of cervical cancer in Angola: social-cultural factors: human papillomavirus (HPV), the necessary cause of cervical cancer, is endemic in Africa. Many of the factors that increase HPV acquisition and promote the oncogenic effect of the virus are also widespread in Angola. These include early marriage, polygamous marriages, and high parity.

Polygamy is accepted in many regions of Angola. In some cultures, very young girls, usually virgins, are given marriage to much older men, some with three or more wives. This practice can increase the likelihood of

Table 1. Number of new cases in 2018 , both sexes, all ages (Angola Source: GLOBOCAN 2018). ${ }^{[x]}$

\begin{tabular}{lcc}
\hline Types & N & $\%$ \\
\hline Cervix uteri & 2,949 & $18.5 \%$ \\
Breast & 2,158 & $13.5 \%$ \\
Prostate & 2,016 & $12.6 \%$ \\
Colorectal & 733 & $4.6 \%$ \\
Hodgkin lymphoma & 631 & $4 \%$ \\
Others cancers & 7,462 & $46.8 \%$ \\
Total & 15,949 & $100 \%$ \\
\hline
\end{tabular}

Table 2. Number of new cases in 2018, males, all ages (Angola Source: GLOBOCAN 2018). ${ }^{[\times]}$

\begin{tabular}{lcc}
\hline Types & $\mathrm{N}$ & $\%$ \\
\hline Prostate & 2,016 & $30 \%$ \\
Liver & 382 & $5.7 \%$ \\
Colorectal & 374 & $5.6 \%$ \\
Non-Hodgkin lymphoma & 339 & $5 \%$ \\
Lip, oral cavity & 241 & $3.6 \%$ \\
Others cancers & 3,379 & $50.2 \%$ \\
Total & 6,731 & $100 \%$ \\
\hline
\end{tabular}


Table 3. Number of new cases in 2018, females, all ages (Angola Source: GLOBOCAN 2018). ${ }^{[\times]}$

\begin{tabular}{lcc}
\hline Types & $\mathbf{N}$ & $\%$ \\
\hline Cervix uteri & 2,949 & $32 \%$ \\
Breast & 2,158 & $23.4 \%$ \\
Ovary & 265 & $2.9 \%$ \\
Non-Hodgkin lymphoma & 292 & $3.2 \%$ \\
Colorectal & 359 & $3.9 \%$ \\
Others cancers & 3,195 & $34.7 \%$ \\
Total & 9,218 & $100 \%$ \\
\hline
\end{tabular}

a girl getting an HPV infection at first sexual intercourse with her husband. Polygamy is reported to increase the risk of cervical cancer by two-fold, and the risk increases with the increasing number of wives. High parity, which is the norm in some cultures, is also a recognized and independent HPV-related cofactor for the development of cervical cancer.

Socioeconomic factors: women around the world with low socioeconomic status have a higher risk of cervical cancer. Cervical cancer is often referred to as a disease of poverty and poor women. Poverty is endemic in Sub-Saharan Africa. A recent study in Mali, West Africa, showed that within a population widely infected with HPV, poor social conditions, high parity, and poor hygiene were the primary co-factors for cervical cancer, in Angola is not different. Poverty, in its many ramifications, is also a significant barrier to the prevention and treatment of this disease.

Biological factors: poor nutritional status and infections, P. malariae, HIV, and tuberculosis are causing many people to be immunologically compromised. Reproductive tract infections are also endemic. Recent studies associate sexually transmitted infections (STIs) other than HPV with cervical cancer.

Cultural, ethnic, and linguistic taboos have a major influence on the increase in cervical cancer cases in Angola. In some regions of Angola, there is a disbelief in Western medicine, medical means, and procedures (in vaccines).

Non-adherence to gynecology consultation, reduced availability of HPV vaccine, and the belief that vaccines make women sterile are cited as critical conditions for the increase in cases.

Illiteracy, low academic level, lack of information, and sex education are proving to be a sine quo condition for the high prevalence of cases. Early age in the first coitus is one of the risk factors for the onset of the disease, in Angola sexual activity generally starts at 13-15 years.

Although polygamy is not constitutionally approved, it is practiced in all regions of Angola; there is an example of a man known worldwide for having 49 women and 160 children in the province of Namibe, southern Angola.

Multiparity is considered a normal phenomenon and prostitution is common in all spheres and regions of the country.
As long as the high numbers of low-educated, lowincome women with peer-to-peer partners, and low-discernment in Western medicine, prevail the numbers will be difficult to reverse.

\section{REFERENCES}

1. World Health Organization (WHO). Advocacy for cervical or cervical cancer prevention and control in Africa: facilitator manual. Brazzaville: WHO; 2017.

2. Schmauz R, Okong P, Villiers EM, Dennin R, Brade L, Lwanga SK, et al. Multiple infections in cases of cervical cancer from a high incidence area in tropical Africa. Int J Cancer. 1989 May;43(5):805-9.

3. Serwadda D, Wawer MJ, Shah KV, Sewankambo NK, Daniel R, Lorincz A, et al. Use of a hybrid capture assay of self-collected vaginal swabs in rural Uganda for detection of human papillomavirus. J Infect Dis. 1999 Oct;180(4):1316-9.

4. Bayo S, Bosch FX, Sanjosé S, Muñoz N, Combita AL, Coursaget $\mathrm{P}$, et al. Risk factors of invasive cervical cancer in Mali. Int J Epidemiol. 2002 Feb;31(1):202-9.

5. Chaouki N, Bosch FX, Munoz N, Meijer C), El Gueddari $B$, El Ghazi A, et al. The viral origin of cervical cancer in Rabat, Morocco. Int J Cancer. 1998 Feb;75(4):546-54.

6. Brinton LA, Reeves WC, Brenes MM, Herrero $\mathrm{R}$, Britton RC, Gaitan E, et al. Parity as a risk factor for cervical cancer. Am J Epidemiol. 1989 Sep;130(3):486-96.

7. Hildesheim A, Herrero R, Castle PE, Wacholder $S$, Bratti MC, Sherman ME, et al. HPV co-factors related to the development of cervical cancer: results from a population-based study in Costa Rica. Br J Cancer. 2001 May;84(9):1219-26.

8. Munoz N, Franceschi S, Bosetti C, Moreno V, Herrero R, Smith JS, et al. Role of parity and human papillomavirus in cervical cancer: the IARC multicentre case-control study. Lancet. 2002 Mar;359(9312):1093-101.

9. Palacio-Mejía LS, Range-Gómez G, Hernández-Ávila M, Lazcano-Ponce E. Cervical cancer, a disease of poverty: mortality difference between urban and rural areas in Mexico. Salud Publica Mex. 2003;45(Suppl 3):S315-S25.

10. Denny $L$. The prevention of cervical cancer in the developing world. BJOG. 2005 Sep;112(9):1204-12. 


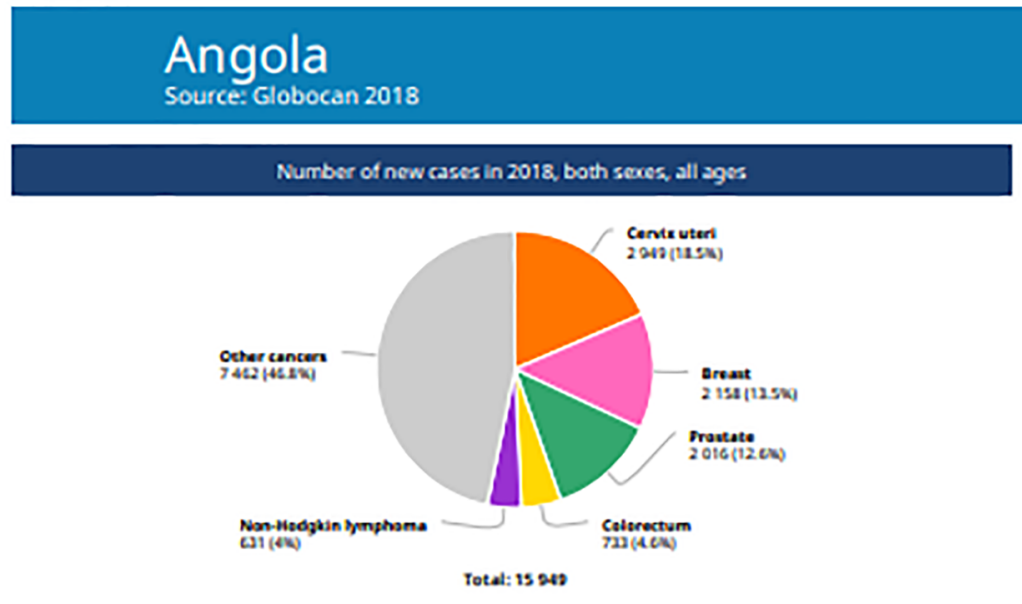

Number of new cases in 2018 moles, all sges

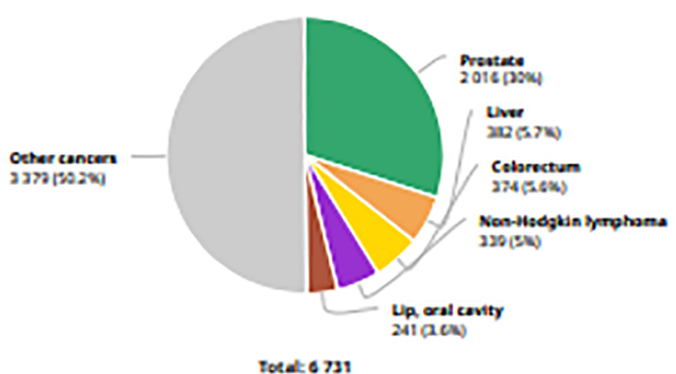

Number of now cases in 2013 , femacs, all ages

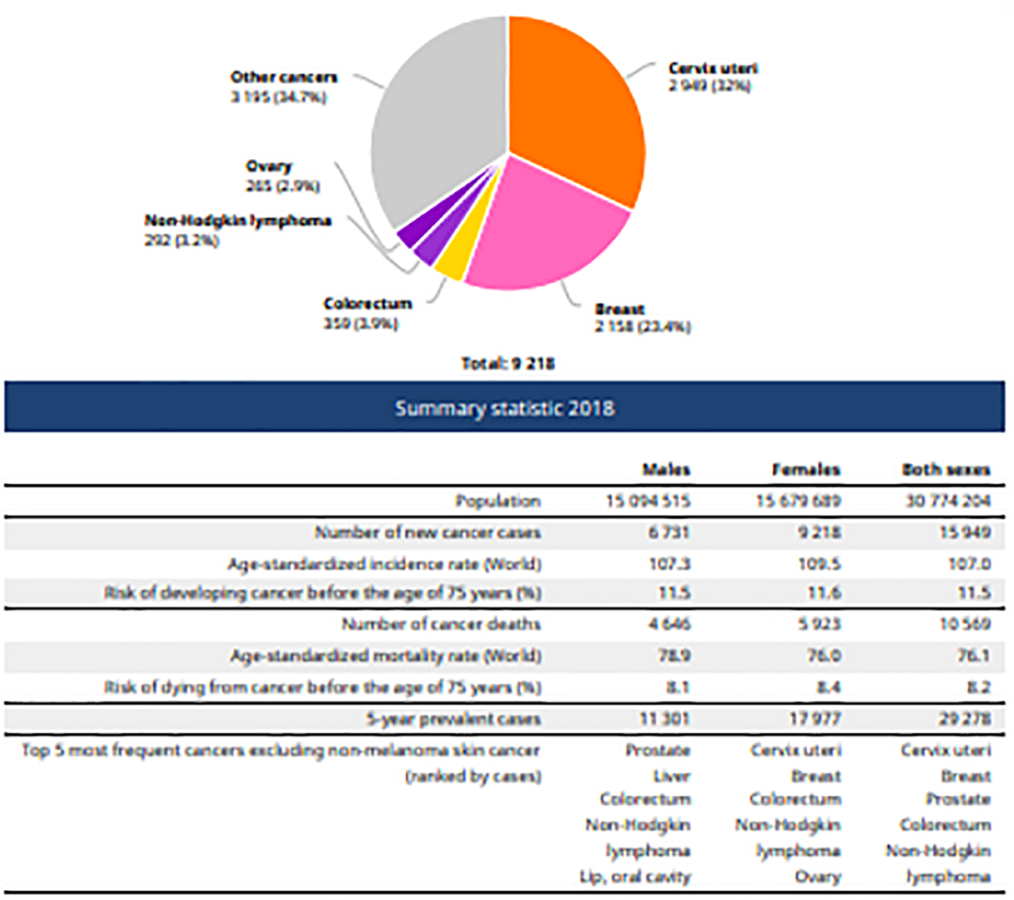

Googrophy

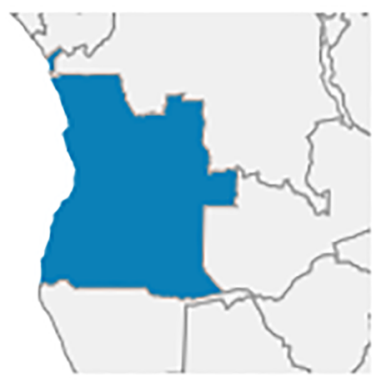

Numbers at a glance

Iocsl populesion

30774204

Namber of new canen

15949

Number of deacta

\section{9}

Number of prowiknt caves (5-yvex) 29278

\section{Daw source and methods}

Encidence

Country-2gecific dota nource: No det

Muebod: No datac the tates are thase of neighbouring countries of rughtries in the watre ares.

Mortalicy

Coestry-apecific data source: Na deta

Mebbed: tstmated trom naticnal ircisence extmates by madeting, uning indidence:mortaliry racion derived from cancer regintry data in neighbouring countries

Drovalence

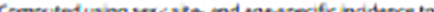

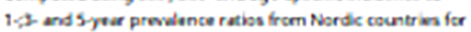
the period $2000200 \mathrm{~m}$, and scaled uning Human Dowelopment inder PDOQ retion 


\section{Angola}

Incidence, Mortality and Provalence by cancer site

\begin{tabular}{|c|c|c|c|c|c|c|c|c|c|c|}
\hline & \multicolumn{4}{|c|}{ New coses } & \multicolumn{4}{|c|}{ Deaths } & \multicolumn{2}{|c|}{ I-veer grevalence (ell ages) } \\
\hline Cascer & Number & $R_{a n k}$ & $(\mathbf{W})$ & Cumrisk & Nember & Sank & (\$) & Cumrik & Nambar & Frep. \\
\hline Cenves uteri & 226 & 7 & 18.5 & 4.02 & 1 128? & 1 & $18 \mathrm{E}$ & 100 & 5225 & 37.15 \\
\hline Breant & 2198 & 2 & 19.5 & 2.75 & 1189 & 3 & 10.8 & 1.51 & 4469 & 2247 \\
\hline Proveate & 2016 & 3 & 12.6 & 4.70 & i & 2 & 10.9 & 250 & 3211 & 2127 \\
\hline Non Hod glen bymphoma & 6נ1 & 4 & 40 & 0.34 & 404 & 6 & $3 \varepsilon$ & 0.26 & 129 & 420 \\
\hline therer & ssi & s & 16 & asi & sot & 4 & 5.2 & מת & Q21 & 202 \\
\hline Leckarmia & 429 & 6 & 2.7 & 0.24 & 200 & 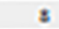 & 23 & 0.23 & ข27 & 101 \\
\hline tung & 413 & J & 26 & 0,42 & $40 \mathrm{~s}$ & s & 20 & 0,2 & $3 n$ & 1.90 \\
\hline Stemach & 304 & 8 & 2.5 & 0.34 & 257 & T & 14 & ar & 507 & 1.ts \\
\hline Colon & $3 \pi$ & 2 & 2.4 & $0 . x$ & 200 & 11 & 26 & 0.85 & $\Delta=0$ & 204 \\
\hline Lip, oral carisy & 15s & 10 & 2.2 & 0.20 & $2 n$ & 10 & 28 & 0.26 & $0 \times 6$ & 220 \\
\hline Orrophengu & 393 & 11 & 2.1 & 0.212 & 317 & ? & 10 & as & 221 & 104 \\
\hline Ocary & 265 & 12 & 1.7 & 0.25 & 212 & 12 & 20 & 0.2 & son & 325 \\
\hline triadder & 261 & 13 & 1.6 & 0.25 & 163 & 13 & 1.6 & 0.16 & ses & ies \\
\hline anctum & 258 & $u$ & 16 & 0.22 & 12 & 17 & 1.3 & 0.13 & 452 & $1 A 7$ \\
\hline Kaposi Larcoma & 235 & is & is & 0.10 & 130 & 20 & 1.2 & 0.05 & 474 & 154 \\
\hline Melancma of whin & 221 & 16 & 2.4 & 0.20 & 12) & 18 & 1.3 & 0.13 & 452 & 187 \\
\hline Wdroy & 201 & 17 & 13 & 0.10 & 113 & 21 & 1.1 & 0.07 & sos & 103 \\
\hline Leypex & 123 & 18 & 122 & e.12 & 147 & 14 & 1.4 & 0.15 & Ien & 120 \\
\hline Mulsple mpeloma & 170 & 10 & 1.1 & 0.17 & 197 & is & 1.4 & 0.15 & 280 & 0.34 \\
\hline Erdin nerwous sptem & 160 & 20 & 10 & 0.08 & ותו & 10 & 1.2 & 0.00 & 220 & 1.56 \\
\hline Dencren & 19s & 21 & 0.97 & a.1s & 181 & 16 & 1.4 & 0.13 & 100 & ass \\
\hline Carpas uteri & 2142 & 22 & $a .2$ & 0.24 & ะ1 & 23 & Q.n & 0.14 & 312 & 200 \\
\hline Modglion b,ymphoms & 117 & 23 & 0.73 & 0.04 & st & 27 & 0.48 & 0.003 & 272 & $0: 5$ \\
\hline Sthvary glands & 104 & 24 & aes & 0.00 & 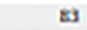 & 22 & 0.20 & 0.00 & $1 n$ & a.ss \\
\hline Wutra & 102 & 2s & 0.64 & 0.15 & 23 & 30 & 0.22 & 0.04 & 202 & 154 \\
\hline Dyprad & 28 & 26 & 0.61 & 0.08 & 20 & $n$ & 0.10 & 0.02 & $23 s$ & an \\
\hline Men & 27 & 27 & $0.6:$ & 0.00 & $\omega$ & 24 & 0.64 & 0.05 & 17 & ass \\
\hline Menh & 22 & $2 s$ & $0.5 s$ & a.13 & 34 & 28 & 0.32 & 0.05 & 184 & 122 \\
\hline Nenopheryex & $n$ & 20 & 0.2 & 0.05 & 54 & 26 & 0.51 & 0.04 & 17 & 0.5 \\
\hline Oropheryex & 70 & 20 & Q.45 & ro. & 62 & 25 & 0.50 & 0.07 & 15: & 0.62 \\
\hline Vagina & 40 & s1 & asi & 0.07 & 21 & 31 & 0.20 & 0.00 & Bs & 0.61 \\
\hline Gelbladder & 36 & $n 2$ & a.s & o.es & 26 & 20 & 0.25 & 0.02 & ss & 0.12 \\
\hline lesth & 30 & Is & 0.12 & 0.03 & 13 & 34 & 0.12 & 0.02 & 24 & ass \\
\hline Hppopharyexx & 16 & 34 & 0.10 & 0.02 & 16 & 33 & Q.15 & 0.02 & 13 & 0.56 \\
\hline Mesctheloma & 11 & Is & 0.07 & 0.01 & 11 & as & 0.10 & 0.01 & 13 & 0.04 \\
\hline All cencer sikes & 15240 & 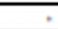 & - & $11, A 8$ & 10960 & 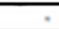 & 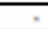 & 3.12 & 20278 & 85.14 \\
\hline
\end{tabular}

Agestandardized (Moric) Incidence rates per sex, top 10 cancers

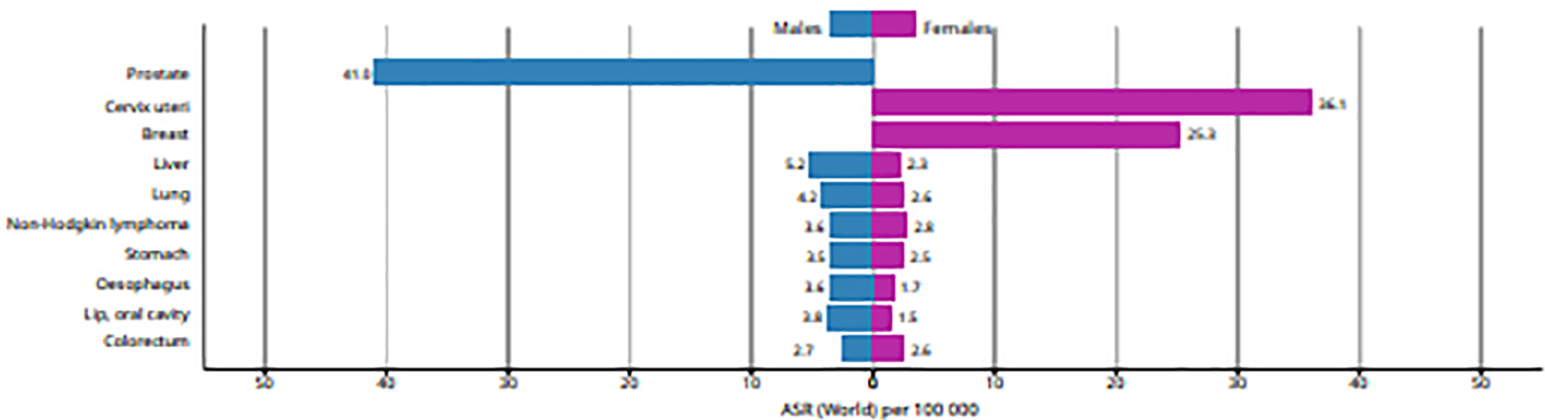

Age:standardzed (World) incidence and mortalty ratea, top 10 cancers

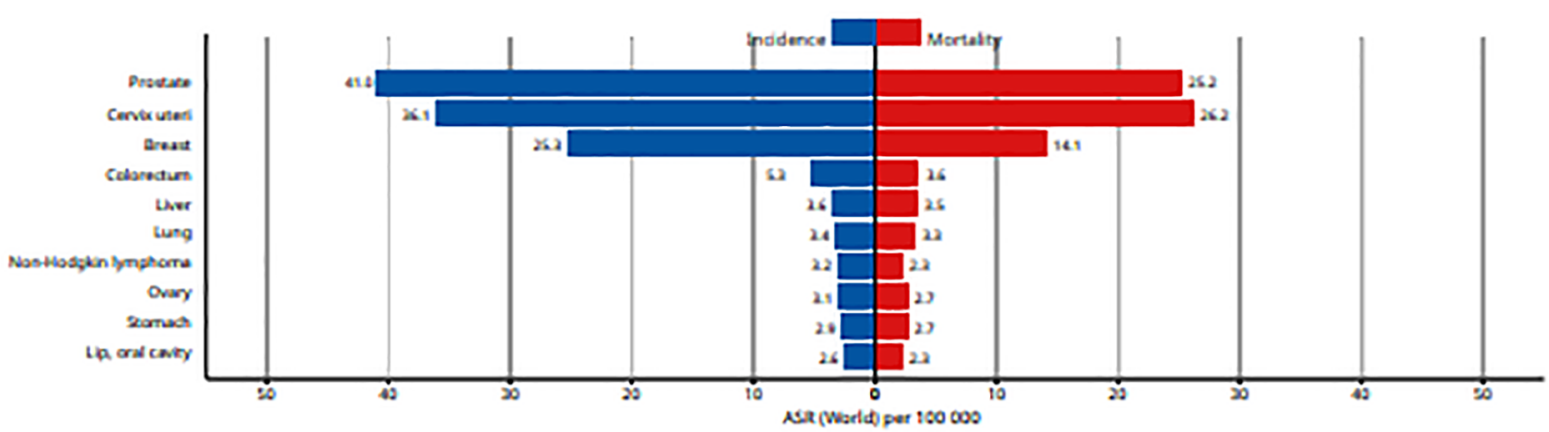

